\title{
P02.185. The effects of tactile massage (TM) on blood pressure, heart rate and blood glucose in a sample of women suffering from primary insomnia
}

\author{
M Sjöling ${ }^{1 *}$, M Jong ${ }^{1}$, K Ljadas $^{2}$, E Englund ${ }^{2}$, J Appelberg ${ }^{2}$ \\ From International Research Congress on Integrative Medicine and Health 2012 \\ Portland, Oregon, USA. 15-18 May 2012
}

\section{Purpose}

The overall objective of this pilot study was to study the direct effects of tactile massage (TM) on blood pressure, heart rate and blood glucose in a sample of women suffering from primary insomnia.

\section{Methods}

The study had an experimental prospective design, with a total of 10 women (mean age; 53 years, \pm 5.4 ). The participants underwent TM twice a week for six weeks resulting in a total of 120 treatments. For short-term effects, systolic and diastolic blood pressure, heart rate and blood glucoses were assessed by the therapist before and after each treatment. Long-term assessments were made at baseline, week 7, and week 13 .

\section{Results}

As a short term result after the treatment with TM, the participants reached a statistically significant reduction of systolic blood pressure $(-5.5 \mathrm{mmHg}, \pm 5.0)$, diastolic blood pressure $(-2.0 \mathrm{mmHg}, \pm 4.4)$, heart rate $(-5.1$ beats per minute, \pm 3.4$)$ and blood glucose $(-0.2 \mathrm{mmol}, \pm 0.5)$. No long-term effects with respect to the studied variables can be observed.

\section{Conclusion}

In summary, we have shown in a normotensive but highly stressed sample of women, that TM has beneficiary effects on parameters of stress and cardiovascular function. In total, $120 \mathrm{TM}$ treatments were analyzed

${ }^{1}$ Mid Sweden University, Sundsvall, Sweden

Full list of author information is available at the end of the article with respect to the objective of the study, but in order to more understand the practical effects, and to more deeply evaluate TM's place in the modalities of stress reduction, we recommend further studies with larger samples.

\section{Author details}

'Mid Sweden University, Sundsvall, Sweden. ${ }^{2}$ Västernorrland County Council, Sundsvall, Sweden.

Published: 12 June 2012

doi:10.1186/1472-6882-12-S1-P241

Cite this article as: Sjöling et al.: P02.185. The effects of tactile massage (TM) on blood pressure, heart rate and blood glucose in a sample of women suffering from primary insomnia. BMC Complementary and Alternative Medicine 2012 12(Suppl 1):P241.

Submit your next manuscript to BioMed Central and take full advantage of:

- Convenient online submission

- Thorough peer review

- No space constraints or color figure charges

- Immediate publication on acceptance

- Inclusion in PubMed, CAS, Scopus and Google Scholar

- Research which is freely available for redistribution 